\title{
Effects of Different Physical Frequency on Food-Dependent Exercise Induced Allergy Anaphylaxis (FDEIA) and Related Mechanisms
}

\author{
Cheol Woo Kim² and Yi Sub Kwak'* \\ ${ }^{1}$ Department of Physical Ecucation, Dong-eui University, Busan 614-714, Korea \\ ${ }^{2}$ Department of Police \& Security Administration, Dong-eui Institute Technology, Busan 614-715, Korea
}

Received February 24, 2012 /Revised April 20, 2012 / Accepted June 29, 2012

Food allergies have become a serious health concern in the past two decades, especially in developed countries. Foods associated with allergies include vegetables, some fruits, shellfish, wheat, egg, chicken, and nuts. To describe the specific fundamentals, etiological factors, and clinical manifestations, we analyzed the different physical frequency on spleen index in sensitized and regular exercise-trained mice. We also conducted a proliferation assay of lymphocytes to OVA, ROS, ASAS, and we determined the cytokine levels. Female BALB/c mice were bred in the animal laboratory of the $\mathrm{P}$ and $\mathrm{D}$ university under controlled conditions $\left(22 \pm 2^{\circ} \mathrm{C}, \mathrm{RH} 45-55 \%\right.$, and a 12-hour photoperiod). The animals were 6 weeks old at the start of the study and were fed a standard commercial chow diet from 09:00 to 15:00 for the 8-week study period. All animals had access to distilled deionized water ad libitum. They were divided into four groups: a control group ( $S$; control sensitized, $n=25)$, a low-frequency training group (F2, $n=25)$, a mid-frequency training group (F3, $n=25)$, and a high-frequency training group ( $F 5, n=25$ ) following the treatment of exercise time per week. The results were as follows: The mice spleen index showed the highest grade in the F5 group compared with the other groups; this level showed in an exercise frequency-dependent manner. In the proliferation assay of OVA, the F5 group showed the highest grade compared with the other groups; this level was also showed in an exercise frequency-dependent manner. Peritoneal ROS and ASAS showed a statistically significant increase in the F5 group and decreased in the F2 group compared with the $S$ group. However, there were no significant differences in the F3 group. The highest level of IL-4 was found in the F5 group compared with the other groups. However, the highest level of INF- $\gamma$ was in the F2 group. The results suggest that FDEIA is positively correlated with the frequency of exercise due to the direct effect of physical exercise on peritoneal ROS and the cytokine profile. Further research is needed on the specific mechanism underlying the combined effects of exercise intensity and frequency on physical-induced allergy anaphylaxis.

Key words : Food-dependent exercise induced allergy anaphylaxis (FDEIA), exercise frequency, cytokine, reactive oxygen species (ROS), active systemic allergy anaphylaxis (ASAS)

\section{서 론}

운동 유발성 알레르기 질환은 운동활동 중이나 운동활동 후에 일어나는 반응으로서 항체 중 $\mathrm{IgE}$ 가 교차연계 되어 매개 된 호염기구(eosinophil)와 비만세포(mast cell)에 의한 반응으 로 과도한 염증반응을 야기하고 세포내 신호를 전달하여 degranulation에 의한 히스타민이나 프로스타글란딘(prostaglandin)을 분비하여 독성을 나타내는 반응으로 정리할 수 있 다[3]. 이 반응은 피부의 두드러기현상, 위장장애, 구역질, 현기 증 및 심혈관 질환, 호흡곤란, 혼수상태 심지어는 알레르기 쇼크사를 유발한다[19]. 이는 격렬한 운동을 5 분 정도 수행한 후에 상기도 수축현상을 일으키는 운동 유발성 천식과는 상이 한 반응으로 상기도 수축현상이 폐를 보호하기 위해 기도가

\footnotetext{
*Corresponding author

Tel : +82-51-890-1546, Fax : +82-51-890-2643

E-mail : ysk2003@deu.ac.kr
}

수축하며 주로 차갑고 건조한 환경에서 발생하는 현상이라면 운동 유발성 알레르기 반응은 과도한 염증을 포함하는 장기간 의 운동강도와 운동빈도가 동반되는 운동 시에 일어나는 현상 이라고 말할 수 있다[11]. 운동 유발성 아나플락시스(exercise induced allergy anaphylaxis)는 운동에 의해 상기도가 좁아지 고 혈압이 떨어져서 쇼크현상을 나타내는 것으로 기관지가 좁 아져 쌕쌕하는 숨소리가 나타나고 혈관부종이나 혼수상태에 이르게 되며, 아나플락시스는 증상이 나타나게 되면 응급치료 가 요구되고 일반적으로 에피네프린(epinephrine) 등 교감신경 자극제와 항히스타민제를 투여하게 되며, 스테로이드를 사용 하기도 한다[2,6]. 운동과 면역반응에 관한 이제까지의 연구들 을 분석해 보면 규칙적인 운동활동은 인체의 세포매개 및 항 체매개 면역반응을 증가 시키고 초기면역을 관장하는 자연살 해 세포(NK cell)의 활성화를 도모하여[8,12], 면역반응에 긍정 적인 영향을 미치지만, 운동이 세포 매개성 면역반응을 관장 하는 $\mathrm{T}$ 세포의 성숙 과정 중 type I T세포와 type II T세포가 
균형 있게 성숙하는 것이 아니라 type II T세포의 과도한 성숙 을 유도하여 알레르기 질환이 더 잘 유발되는 것으로 확인되 었다[8].

운동 유발성 알레르기 질환은 섭취한 특정 음식 항원과 연 계되어 일어나는 경우가 일반적인데, 이를 식이유도 운동 유 발성 알레르기 질환이라고 한다. 알러젠(allergen) 음식 섭취 후 몇 시간이 경과하지 않은 상태에서 운동하는 경우 운동 중이나 운동 후에 알레르기가 유발되는데, 이러한 음식의 종 류로는 계란, 갑각류, 콩, 밀, 고등어, 굴, 과일 등이 보고되고 있다[18]. 운동은 알레르기 질환을 가속화하고 알레르기 질환 을 가지고 있는 환자는 한가지 이상의 알레르기 질환을 가지 는 알레르기 행진을 경험하게 된다. 증상으로는 가려움증, 두 드러기, 홍반, 혈관부종, 심혈관계 질환, 무기력, 혼수상태, 아 나플락시스 등이 보고되고 있다[1]. 이러한 증상은 알러젠 음 식섭취와 운동뿐만 아니라 피로감, 감기, 불충분한 수면, 스트 레스, 추운 환경, 아스피린섭취 등도 관련되어 이 질환을 가속 화하는 것으로 보고되고 있다[10].

최근 활성산소의 생성과 알레르기 질환의 가속화와 연관성 이 있는 것으로 보고되어 알레르기 질환이 활성산소에 의해 어느 정도 활성화 및 조절되어 짐이 밝혀졌다[8]. 이러한 증상 으로부터 피하기 위해서는 예방하는 것이 최선이며, 개인이 가지는 음식항원을 미연에 파악하여 피하는 것이 좋고, 식사 후 최소한 몇 시간이 지난 후에 운동활동에 참여하는 것이 좋은 것으로 여겨진다. 또한 최근 연구결과를 보면 항 히스타 민제나 스테로이드와 같은 약물뿐만이 아니라 비타민 C의 투 여가 복강세포의 활성산소를 감소하여 운동 유발성 알레르기 질환을 어느 정도 감소시키는 것으로 보고되었는데[8], 이는 투여된 비타민이 생체 내 활성산소를 감소시키는데 도움을 주어 알레르기 질환을 감소시키는 것으로 사료된다.

운동처치의 측면에서 식이유도성 운동 유발성 알레르기 질 환을 예방하기 위해서 시즌 중 운동활동을 중단하는 detraining을 하거나 전혀 다른 종류의 운동활동을 수행하는 cross training이 효과적이라고도 보고되고 있는데, 운동방법의 차 이도 이 질환에 큰 영향을 주는 것으로 밝혀졌다[18].

운동활동에 따른 식이유도 운동 유발성 알레르기 질환에 대한 연구는 이제까지 운동활동에 따른 알레르기 질환의 원인 및 증상에 관한 연구[1], 이 질환에 대한 생리 및 병리에 대한 연구[10], 예방 및 치료에 대한 연구[5,13]와 사례연구 등이 보 고되고 있다[20]. 하지만 이제까지 운동강도와 운동빈도의 차 이가 식이유도 운동 유발성 알레르기 질환에 중요한 변인임을 알 수 있지만, 이제까지 이에 대한 기전적 연구가 미미하다.

선행 연구에서 운동강도에 따른 식이유도 운동 유발성 알레 르기 질환의 정도를 살펴본 결과 운동강도가 높을수록 식이유 도 운동 유발성 알레르기 질환의 정도가 크게 나타남을 확인 할 수 있었다[9]. 이 연구에서는 30 분간의 운동그룹에 비하여 50 분, 50 분에 비해 80 분간의 운동활동그룹에서 식이유도 운동 유발성 알레르기 질환이 더 잘 유도됨을 확인 할 수 있었다.
따라서 본 연구에서는 선행 연구결과를 바탕으로 적절하게 알레르기가 유발되는 50 분간의 운동강도를 선정하여 운동빈 도를 서로 달리하여 저빈도 그룹( $\mathrm{F} 2$, 주2회), 중빈도 그룹( $\mathrm{F} 3$, 주 3회) 및 고빈도 그룹(F5, 주5회)으로 나누어 훈련을 부여하 고 ovalbumin (OVA) 알부민으로 감작하여 challenge를 하였 을 때, 알레르기 아나플락시스의 변화 양상 차이를 살펴보고 동시에 기전변화를 함께 규명하고자 하였다.

\section{재료 및 방법}

\section{실험동물 그룹}

본 실험을 위하여 무 병원성 환경(Pathogen free system)에 서 사육한 생후 6주령의 BALB/c 마우스(female)를 HC 동물 센타에서 구입하고 이들 마우스를 P대학교와 D대학교 동물실 험실에서 사육 및 처치하여 본 실험에 이용하였다. 그리고 운 동강도에 따른 식이유도 알레르기반응의 결과 적절한 알레르 기 반응을 일으키는 운동강도인 50 분간의 운동강도(중강도의 운동)를 결정하고 운동빈도를 서로 달리하여 통제그룹을 포함 하는 저빈도 그륩(F2, 주2회), 중빈도 그룹(F3, 주 3회) 및 고빈 도 그룹(F5, 주5회)의 4 그룹으로 나누어 훈련을 부여하고 OVA 알부민으로 감작하고 challenge하였을 때, 알레르기 아 나플락시스의 변화양상 차이를 살펴보았으며, 알레르기 아나 플락시스를 조사하고 세포를 분리하여 분석 및 실험하였다.

각 그룹당 25마리씩 통제군(S; control sensitized, n=25), 저 빈도 훈련군(F2, $\mathrm{n}=25)$, 중빈도 훈련그룹( $\mathrm{F} 3, \mathrm{n}=25)$ 및 고빈도 훈련그룹( $\mathrm{F} 5, \mathrm{n}=25)$ 으로 구분하여 수영훈련 빈도에 따른 알레 르기를 유도하였을 때, 알레르기 아나플락시스를 조사하고 아 울러 면역력의 유도여부와 알레르기의 정도 및 알레르기 기전 확인을 분석하기 위해 비장지수, 림프구의 수, 복강 reactive oxygen species (ROS), active systemic allergy anaphylaxis (ASAS), 및 싸이토카인(INF- $\gamma$, IL-4)의 변화를 함께 측정하였 다. 이 때, 알레르기 아나플락시스 테스트는 그룹당 10 마리를 사용하였고 나머지는 세포분석, 싸이토카인분석, 및 ROS 측 정을 위하여 사용하였다.

\section{실험동물의 수영훈련}

실험동물의 사육실은 clean 사육실로서 온도 $22 \pm 2^{\circ} \mathrm{C}$, 습도 $50 \pm 5 \%$, 소음(40-50 Phon 이하) 및 조명(12시간 명/암)이 자동 적으로 제어되도록 하였으며, 무균음료 및 멸균사료를 자유롭 게 섭취 하도록 하였다. 훈련그룹으로 분류된 실험동물은 1 주 간의 환경적응과 1 주간의 수영 적응훈련기간을 가진 후 적응 여부를 가려, 8 주 동안 본 훈련을 실시하였다.

본 실험의 수영 적응훈련으로는 같은 시간대에 최초 10 분부 터 30 분까지 매일 5 분간 시간을 점증적으로 증가시키며 실시 하였고, 본 훈련 8 주 동안은 같은 시간대에 운동시간을 50 분으 로 정하고 각 빈도별 저빈도, 중빈도 및 고빈도 그룹으로 구분 하여 수영훈련을 실시하였다. 
이 때, 사용된 pool은 $900 \times 450 \times 450 \mathrm{~mm}$ 규격을 사용하며 수온은 섭씨 $27-29^{\circ} \mathrm{C}$ 를 유지하도록 하였다[14]. 한편, 통제그 룹은 훈련그룹이 훈련을 하는 동안 같은 수조 내의 같은 수온 에 몸만 잠기게 통제하며, 수영 스트레스를 최소화하기 위해 물은 매일 교체하는 등 깨끗한 환경을 유지하도록 하였다.

\section{식이유도 운동 유발성 알레르기 유도 및 판정}

마우스에게 운동 유발성 알레르기 면역반응을 유도하기 위 하여, 실험동물을 1 주간의 환경적응과 1 주간의 수영적응 훈련 을 포함하는 8주간의 수영훈련을 실시한 후 OVA를 adjuvant 인 aluminium hydroxide $(20 \mathrm{\mu g} /$ mouse $)$ 및 Bordetella pertussis 사균 부유액 $\left(1 \times 10^{9}\right.$ bacteria/마우스)과 혼합하여 마우스 복 강(i.p)으로 1회 투여하였으며, 이때 투여된 OVA의 양은 선행 연구의 결과에 따라[7] 알레르기가 잘 유발되는 용량인 마우스 당 $1 \mathrm{mg}$ 이 되도록 하였다. OVA에 대한 알레르기 유발의 판정

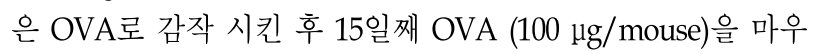
스 꼬리정맥으로 투여하고(i.v.) Haffner (Table 1) [7]의 방법에 준하여 알레르기 유발을 판정하였다.

\section{비장 Index의 측정}

알레르기 면역감작 후 감작된 정도를 비교하기 위하여 Chandra와 그의 동료들에 의한 연구방법[4]에 따라 비장 in$\operatorname{dex}$ 를 측정하였으며, 알레르기가 유도될 때 비장의 크기가 병 적으로 커지는 지에 대하여 확인하였다.

* 비장 index=spleen weight/animal weight

\section{복강의 대식세포와 비장의 $\mathrm{T}$ 림프구 및 $\mathrm{B}$ 림프구의 분리}

복강의 대식세포를 분리하기 위하여, 수영훈련 기간별 훈련 된 마우스를 $\mathrm{CO}_{2}$ gas로 희생시키고, 우태아 혈청이 함유되지 않은 RPMI 1640 배지(2 mM L-glutamine, $2.2 \mathrm{mg} / \mathrm{ml}$ sodium bicarbonate, 100 units $/ \mathrm{ml}$ penicillin, $100 \mu \mathrm{g} / \mathrm{ml}$ streptomycine, 및 $2 \mathrm{mM} \mathrm{HEPES}$ buffer가 첨가됨) $10 \mathrm{ml}$ 를 $10 \mathrm{ml}$ 주사기 (18 gauge needle)에 넣어 마우스 복강 내로 2-3회 주사하고

Table 1. Scoring of active systemic anaphylaxis (ASAS) Shock score Sign

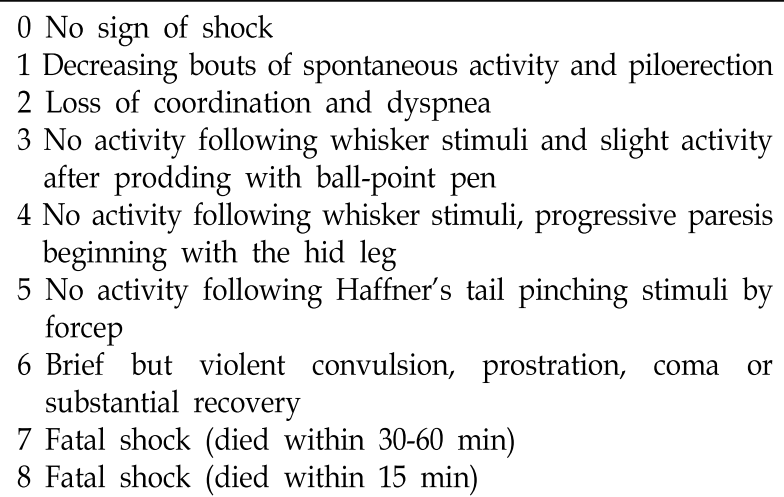

4 No activity following whisker stimuli, progressive paresis beginning with the hid leg

5 No activity following Haffner's tail pinching stimuli by forcep

6 Brief but violent convulsion, prostration, coma or substantial recovery

7 Fatal shock (died within $30-60 \mathrm{~min}$ )

8 Fatal shock (died within $15 \mathrm{~min}$ )

복강 세척액을 채취하였다. 이 세척액에서 세포를 분리하여 우태아 혈청이 $10 \%$ 함유된 RPMI 1640 배지에 부유시킨 $\left(1 \times 10^{6}\right.$ cells $/ \mathrm{ml}$ ) 후 $75 \mathrm{~cm}^{2}$ culture flask에 넣어 $37^{\circ} \mathrm{C}, 5 \% \mathrm{CO}_{2}$ 항온 항습기에서 3시간 동안 배양하였다. 배양 후 culture flask로부 터 flask 표면에 부착되지 않은 세포는 RPMI 1640배지로 3회 세척하여 제거하고 flask 표면에 부착된 세포는 차가운 배지와 rubber policeman을 이용하여 flask로부터 떼어내어 완전배지 에 $1 \times 10^{6}$ cells $/ \mathrm{ml}$ 로 부유시켰다.

한편 비장의 $\mathrm{T}$ 림프구 및 $\mathrm{B}$ 림프구 분리를 위해 비장으로부 터 분리한 림프구 부유액에서 적혈구는 ACK lysing buffer를 사용하여 제거하고 Dynabeads mouse pan $T$ 또는 pan B를 이용하여 Thy 1.2 또는 B 220 양성세포인 T 림프구 또는 B 림프구를 분리하고 완전배지에 $1 \times 10^{6} \mathrm{cells} / \mathrm{ml}$ 로 부유시켰다.

\section{림프구 증식반응}

림프구의 증식 측정은 $\left[{ }^{3} \mathrm{H}\right]$-thymidine $\left({ }^{3} \mathrm{H}-\mathrm{TdR}\right)$ incorporation 방법에 의해 시행하였다. 우선 림프구 부유액 100 $\mu \mathrm{l} \quad\left(\mathrm{I} \times 10^{5}\right.$ cells $)$ 를 96-well round bottomed microplate (Corning, Rochester, NY)에 분주하고, $10 \mu \mathrm{g} /$ well의 OVA를 첨가하여 4 일간 배양하였다. 배양 후 이 plate의 각 well에 10 $\mu \mathrm{l}(1.0 \mu \mathrm{Ci})$ 의 ${ }^{3} \mathrm{H}-\mathrm{TdR}$ (New England Nuclear, Boston, MA)을 첨가하고 6시간 연장 배양하였다. 각 well에 배양된 세포들은 glass filter에 흡착시키고 beta counter로 ${ }^{3} \mathrm{H}-\mathrm{TdR}$ 의 조사량을 측정하여 세포의 증식 반응을 산정하였다.

\section{복강추출세포에 의해 생성된 ROS 측정}

완전배지에 $5 \times 10^{5} \mathrm{cells} / \mathrm{ml}$ 로 부유시킨 비장 림프구와 복강 추출세포 부유액 $500 \mu \mathrm{l}$ 에 $1 \mathrm{mM}$ 5-(and-6)-chloromethyl$2^{\prime}, 7^{\prime}$-dichlorodihydro-fluorescein diacetate (Molecular Probes, Eugene, Oregon, USA)를 $5 \mu \mathrm{l}$ 첨가하여 혼합한 후 $37^{\circ} \mathrm{C}, 5 \% \mathrm{CO}_{2}$ 항온 항습기에서 10 분간 배양하고 ice에 넣어 반응을 중지시키고 유세포 분석기(FACscan, Becton dickinson)를 이용하여 fluorescence를 측정하여 win MDI로 중앙 값을 나타내었다.

\section{Interferon-gamma $\quad($ IFN- $\gamma)$ 및 $\quad$ interleukine-4 $\quad$ (IL-4)} 의 생성과 측정

림프구의 IFN- $\gamma$ 또는 IL-4 생성을 위하여 림프구 부유액 $1 \mathrm{ml}\left(\mathrm{I} \times 10^{6}\right.$ cells $)$ 를 24 well culture plate에 분주하고 $100 \mu$ $\mathrm{g} / \mathrm{well}$ 의 OVA를 첨가하여 4 일간 자극한 후 상층액을 취하여 $-70^{\circ} \mathrm{C}$ 에 보관하였다. 상층액 내의 IFN- $\gamma$ 및 IL- 4 의 함량은 ELISA를 이용한 Mouse IFN- $\gamma$ assay kit (Endogen Inc. MA) 와 Mouse IL-4 assay kit (Endogen)를 사용하여 측정하였다.

\section{채혈}

식이 섭취에 의한 일시적인 체중 변화를 막기 위해 체중 
측정 12 시간과 1 시간 전에 각각 사료와 음료의 섭취를 제한하 였다. 적응훈련과 본 훈련이 끝난 실험동물들은 동물 수술실 도착 후, 충분한 안정을 취한 뒤 $\mathrm{CO}_{2}$ gas로 희생시켜 마취시키 고, 실험동물을 해부판에 고정한 후, 복부를 절개하여 복부 대정맥에서 정맥혈 $1 \mathrm{ml}$ 을 채취하였다.

\section{통계처리}

본 연구에서 얻은 자료의 통계처리는 SPSS (version 14) 통 계 package를 이용하여 기술 통계량을 산출하고, 통계치의 유 의성은 항목별 one-way ANOVA로 분석하였으며 그룹 간의 의의는 turkey's post hoc으로 사후 검증하였다 $(p<0.05)$.

\section{결과 및 고찰}

본 연구에서는 서로 다른 운동 빈도의 차이가 규칙적인 운 동 활동을 수행한 개체에서 OVA(ovalbumin)로 알레르기를 유발하여 운동 유발성 알레르기 질환의 정도와 기전을 분석하 고, 운동 유발성 알레르기 질환이 가장 크게 나타나는 그룹을 중심으로 운동 유발성 알레르기 질환이 어떠한 기전으로 유발 하였는지를 분석하고자 하였고 이러한 질환이 복강에서 발생 하는 활성 산소종과는 어떠한 연관성을 가지는지를 밝히고자 하였다.

또한 알레르기 아나플락시스를 유발하는데 있어 type II 싸 이토카인의 활성과는 어떠한 연관이 있는지를 확인하고자 하 였다. 운동방법에 있어 운동강도는 적당하게 알레르기를 잘 유 도하는 50 분으로 선정하였고, 서로 다른 운동빈도로 훈련하였 을 경우 알레르기의 양상이 어떻게 차이 나는지를 확인 하였다.

한편 본 연구에서는 운동시간을 고정하고 운동 빈도를 달리 하였을 때, 운동 빈도별 알레르기 아나플락시스의 변화 양상 이 어떠한 차이를 보이는지 살펴보고 동시에 기전변화를 함께 규명하여 운동 유발성 알레르기가 일어나는 규칙적인 운동을 수행하는 운동선수, 동호인 및 일반인들에게 연구결과를 소개 하고자 하였다. 본 연구결과는 다음과 같다.

우선 운동빈도의 변화에 따라 알레르기반응이 일어났는지 를 파악하는 비장지수의 변화는(Fig. 1)에 나타나있다. 감작군 의 비장지수는 0.125 , 저빈도 그룹은 0.126 , 중빈도 그룹은 0.128 , 및 고빈도 그룹은 0.145 로 나타나 감작그룹에 비해 고빈 도 그룹에서 비장지수가 통계적으로 유의하게 증가하였지만 다른 그룹에서는 통계적인 유의성을 보이지 않았다(p>0.05). 다른 그룹간의 차이에서는 저빈도 운동그룹 및 중빈도 운동그 룹과 고빈도 운동그룹에서 유의한 차이를 나타내었다 ( $p<0.05)$. 이러한 결과는 훈련그룹에서 운동빈도에 따라서 알 레르기 감작이 더 잘 유발됨을 알 수 있고, 저빈도에서는 비장 지수의 증가가 일어나지 않지만, 고빈도 운동그룹에서 알레르 기 반응이 잘 유발됨을 확인 할 수 있었다. 본 연구결과는 운동 의 기간이 길수록 알레르기가 더 잘 유도된다는 선행연구와

\section{Spleen Index}

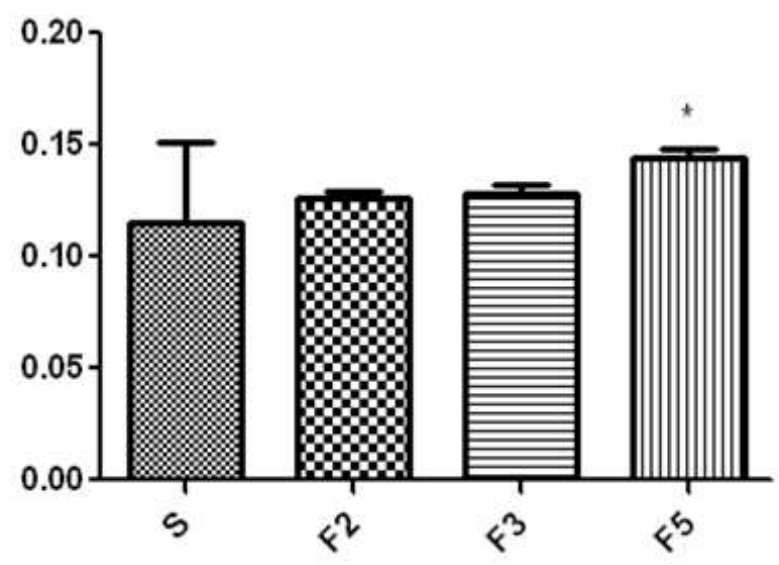

\begin{tabular}{|c|l|l|l|}
\hline & & & \\
\hline ANOVA Table & SS & df & MS \\
\hline Treatment (between columns) & 0.004392 & 3 & 0.001464 \\
\hline Residual (within columns) & 0.01234 & 36 & 0.0003427 \\
\hline Total & 0.01673 & 39 & \\
\hline
\end{tabular}

Fig. 1. The change of spleen index. S: sensitized; F2: 2 times/wk; F3: 3 times/wk; F5: 5 times/wk

비슷한 결과로 운동의 기간과 빈도의 차이가 알레르기 면역유 도와 깊은 연관이 있음을 확인할 수 있다[15].

실험 유발 후 림프구 증식을 보는 실험에서 감작시킨 물질 (ovalbumin, OVA)로 자극한 결과감작그룹은 $6.49 \times 10^{3} \mathrm{cpm}$, 저빈도 그룹은 $6.64 \times 10^{3} \mathrm{cpm}$, 중빈도 그룹은 $6.68 \times 10^{3} \mathrm{cpm}$, 및 고빈도 그룹은 $7.90 \times 10^{3} \mathrm{cpm}$ 으로 나타나 감작그룹에 비해 고빈도 그룹에서 통계적인 유의성을 나타내었다( $p<0.05)$. 하 지만 저빈도 그룹과 중빈도 그룹은 통계적인 차이를 나타내지 않았다( $p>0.05$ )(Fig. 2).

그룹간의 차이에서는 저빈도 운동그룹 및 중빈도 운동그룹 과 고빈도 운동그룹에서 유의한 차이를 나타내었다( $p<0.05)$. 이는 OVA에 대한 반응 시 고빈도 운동그룹에서만 알레르기 반응이 증가됨을 시사하는 것이다. 본 연구결과는 운동의 빈 도와 기간이 길수록 림프구의 증식이 더 잘 유도 된다는 선행 연구결과와 일치하는 것으로 운동의 빈도가 중요하게 작용함 을 확인할 수 있다[15].

운동빈도에 따른 알레르기반응에서 복강 ROS의 변화는 Fig. 3에 나타나있다. 감작그룹의 복강 ROS는 176.4, 저빈도 그룹은 164.4, 중빈도 그룹은 176.6, 및 고빈도 그룹은 191.3로 나타나 감작그룹에 대해 저빈도 그룹은 통계적으로 현저하게 감소하였고 $(p<0.05)$, 반면에 고빈도 그룹은 통계적으로 유의 하게 증가하였다( $p<0.05)$. 그룹간의 차이에서도 감작그룹과 중빈도 그룹간에만 유의한 차이를 보이지 않고, 다른 그룹간 에는 유의한 차이를 나타내었다( $p<0.05)$. 이는 운동이 알레르 기 반응을 증가한다고 하는 사실을 나타내어주지만, 오히려 
OVA

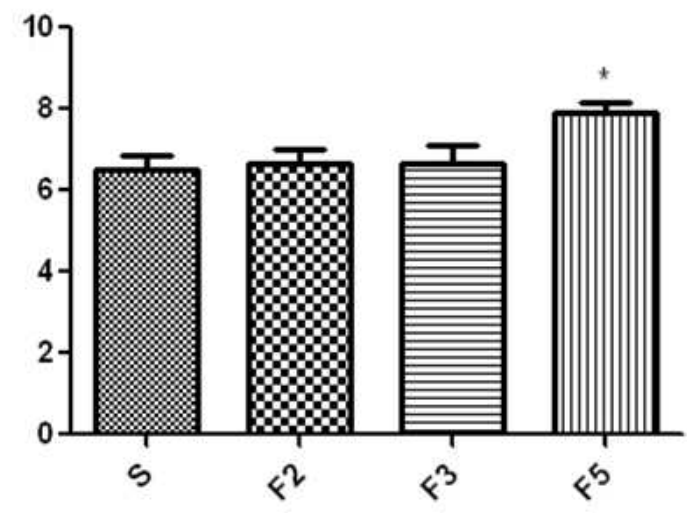

\begin{tabular}{|c|l|l|l|}
\hline & & & \\
\hline ANOVA Table & SS & df & MS \\
\hline Treatment (between columns) & 12.81 & 3 & 4.270 \\
\hline Residual (within columns) & 4.869 & 36 & 0.1353 \\
\hline Total & 17.68 & 39 & \\
\hline
\end{tabular}

Fig. 2. The change of lymphocytes to OVA stimulation. S: sensitized; F2: 2 times/wk; F3: 3 times/wk; F5: 5 times/wk

peritoneal ROS

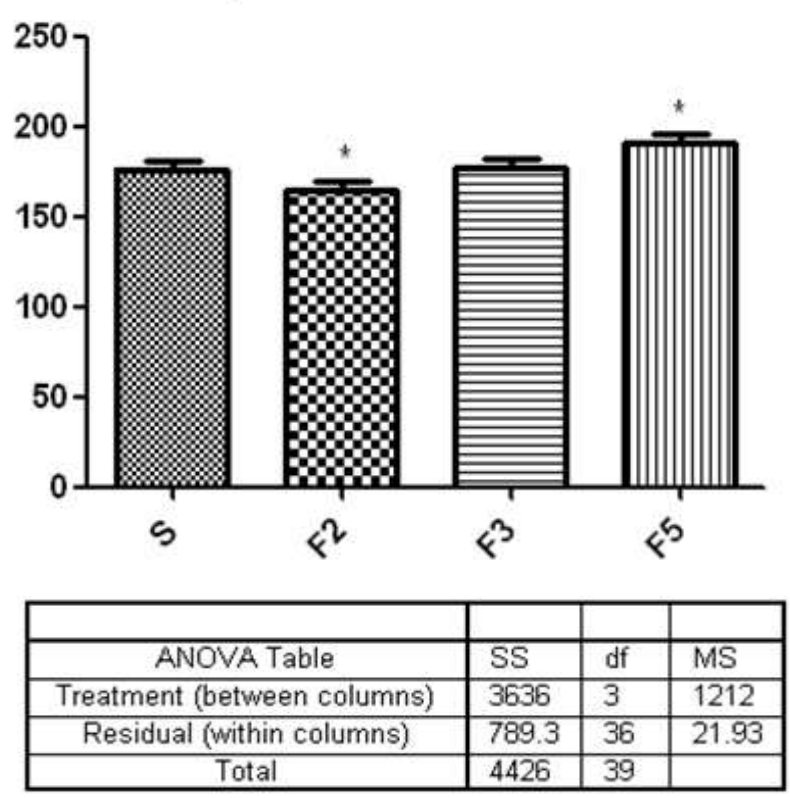

Fig. 3. The change of peritoneal ROS. S: sensitized; F2: 2 times/wk; F3: 3 times/wk; F5: 5 times/wk

저빈도 그룹에서는 운동이 활성산소의 감소를 도모하여 알레 르기반응을 억제하는 효과가 있음을 시사하는 것으로 해석된 다. 이는 저 빈도의 운동이 활성산소의 감소를 도모한다는 선 행연구결과와 일치하는 것으로[8], 감소된 활성산소는 알레르 기반응의 감소를 시사한다고 할 수 있다. 이와는 반대로 고빈 도 그룹에서는 복강 ROS의 현저한 증가를 확인 할 수 있으며,
ASAS

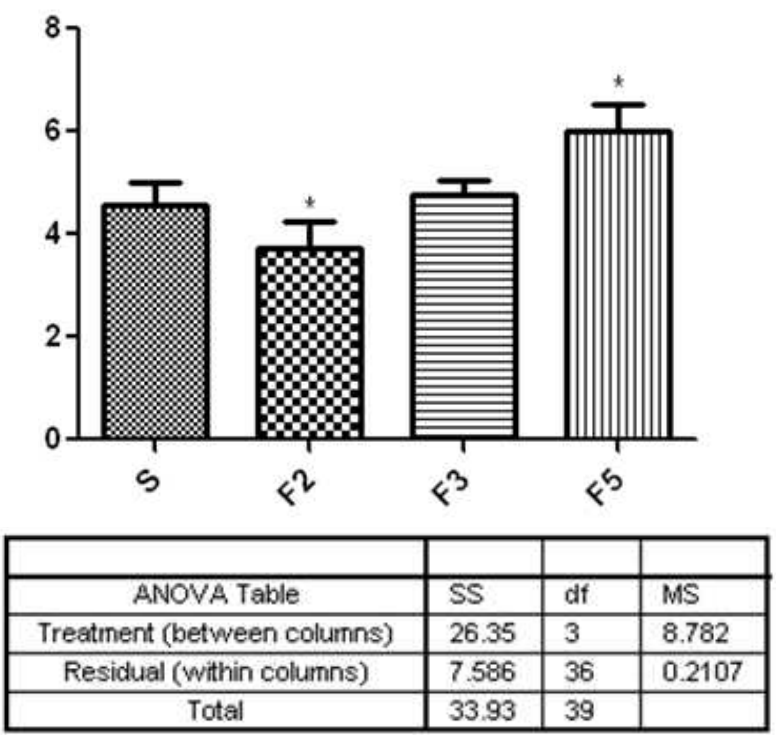

Fig. 4. The change of ASAS. S: sensitized; F2: 2 times/wk; F3: 3 times/wk; F5: 5 times/wk

이는 고빈도 그룹에서 증가한 알레르기반응과 일맥상통하는 것으로 해석할 수 있다.

운동빈도에 따른 알레르기 쇼크사(ASAS)(Table 1)를 확인 하는 실험에서 감작그룹에 비해 저빈도 운동그룹은 현저하게 알레르기 쇼크사 점수가 감소하였으며( $p<0.05)$, 고빈도 운동 그룹에서는 쇼크사 점수가 현저하게 증가하는 것으로 나타났 다(Fig. 4). 그리고 중빈도 그룹에서는 큰 차이를 보이지 않았 고, 그룹간에도 감작그룹과 중빈도 그룹에서만 유의한 차이를 보이지 않았다( $p>0.05)$. 이는 운동 유발성 알레르기 반응에서 운동의 강도도 중요하게 작용하지만 운동의 빈도도 중요한 요인이라고 할 수 있으며, 적은 빈도의 운동은 알레르기 반응 을 오히려 감소시키지만, 고빈도의 운동이 운동 유발성 알레 르기 반응을 현저하게 증가시키는 것으로 해석할 수 있다. 이 러한 결과는 복강 활성산소가 저강도 운동그룹에서 감소하는 것과 일치되는 결과라고 할 수 있으며, 운동의 빈도와 기간이 증가할수록 알레르기반응이 증가한다는 선행연구와 일치하 는 결과라고 할 수 있다[16,17].

본 연구에서는 운동빈도에 따른 알레르기 아나플락시스가 어떻게 차이 나는 가를 규명하였고, 그 기전을 분석하기 위해 대표적인 싸이토카인을 분석하였다.

우선 INF- $\gamma$ 는 운동 활동에 따라 증가하였는데(Fig. 5), 감 작그룹은 $47.8 \mathrm{pg} / \mathrm{ml}$, 저빈도 그룹은 $121.8 \mathrm{pg} / \mathrm{ml}$, 중빈도 그 룹은 $115.8 \mathrm{pg} / \mathrm{ml}$, 및 고빈도 그룹은 $116.2 \mathrm{pg} / \mathrm{ml}$ 을 나타내었 다. 연구결과 감작그룹에 비하여 모든 그룹에서 통계적으로 유의하게 증가하였으며, 저빈도 그룹에서 가장 높은 값을 보 였다. 이는 INF- $\gamma$ 가 운동반응에는 유의하게 증가하지만, 알 


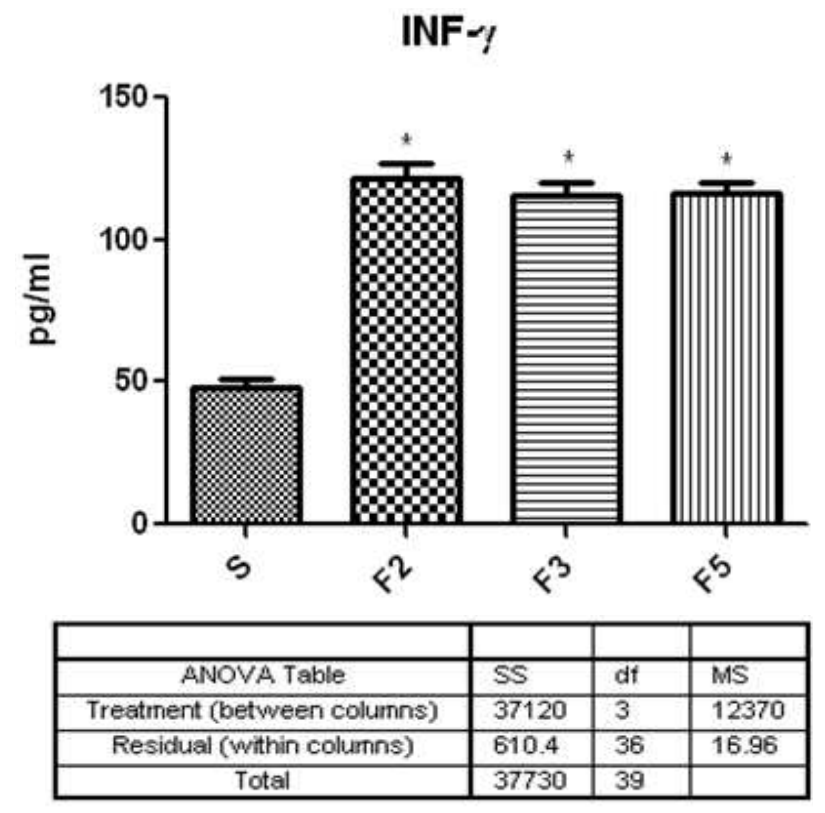

Fig. 5. The change of INF- $\gamma$. S: sensitized; F2: 2 times/wk; F3: 3 times/wk; F5: 5 times/wk

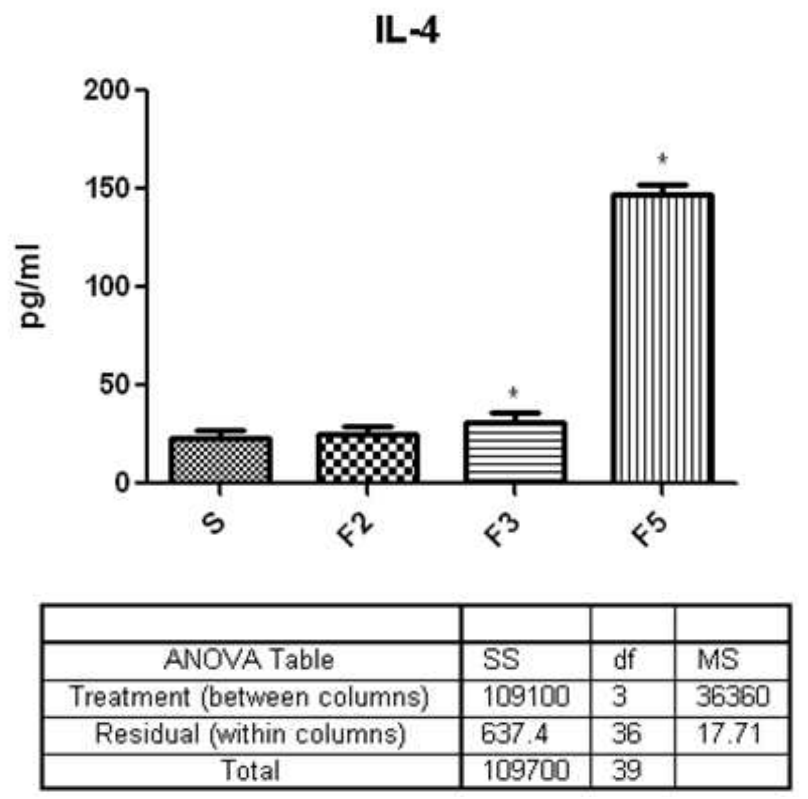

Fig. 6. The change of IL-4. S: sensitized; F2: 2 times/wk; F3: 3 times/wk; F5: 5 times/wk

레르기 반응과는 상이하게 발현하는 싸이토카인이기 때문으 로 사료된다.

IL-4는 대표적인 알레르기 반응과 관련 있는 싸이토카인으 로 감작그룹 $23.6 \mathrm{pg} / \mathrm{ml}$, 저빈도 그룹 $25.5 \mathrm{pg} / \mathrm{ml}$, 중빈도 그 룹 $30.6 \mathrm{pg} / \mathrm{ml}$, 및 고빈도 그룹 $147.3 \mathrm{pg} / \mathrm{ml}$ 을 보여 감작그룹 에 대해 중빈도 및 고빈도 그룹에서 통계적으로 유의하게 증 가하였고(Fig. 6), 고빈도 그룹에서 가장 높은 값을 보여, 운동 빈도에 따라 IL-4의 값이 증가하는 것으로 나타났다. 그룹 간
에는 감작그룹과 저빈도 그룹에는 통계적인 차이가 나타나지 않았고, 다른 그룹 사이에는 모두 유의한 차이를 보였다. 본 연구결과 운동빈도가 IL-4의 발현에 직접적인 연관이 있음을 알 수 있고, 운동빈도가 증가함에 따른 IL-4의 증가가 ASAS의 점수를 증가 시킨 것으로 해석할 수 있다. 이러한 결과는 운동 의 기간과 빈도가 증가함에 따라 알레르기 반응이 증가한다는 선행연구를 반영하는 것으로 운동시 운동의 강도뿐 만이 아니 라 운동의 빈도를 조절하는 것이 운동 유발성 알레르기 질환 을 미연에 예방할 수 있음을 시사한다.

따라서 본 연구의 결과는 추후 인간을 대상으로 하는 연구 의 기초자료가 될 수 있으며, 인간을 대상으로 적용 해 볼 때, 음식 알레르기가 있는 사람은 운동시 항상 알레르기 반응에 유의해야 하며, 운동을 하더라도 알러젠 항원을 피하는 식사 와 식후 일정 시간이 지난 후 운동해야 함을 유념해야 한다. 운동처방 시에도 운동 알레르기가 있는 경우 고빈도, 고강도 의 운동 보다는 저빈도 및 저강도의 운동을 해야 한다는 결론 을 내릴 수 있으며, 오히려 저빈도의 운동은 운동 유발성 알레 르기 반응의 치료에 도움이 된다는 점을 인식해야 한다.

따라서 식이유도 알레르기 질환을 가지는 환자에게 운동을 수행할 경우 훈련 중 detraining 혹은 cross training 방법의 적용도 큰 도움이 될 것으로 사료된다. 본 연구를 통하여 운동 을 지도하는 체육교사나 코치 및 지도자들이 운동을 하는 동 호인이나 운동선수들에게 운동과 알레르기의 연관성에 대한 정보를 제공 및 활용할 수 있게 하고, 트레이닝 방법이나 운동 처방에 활용할 수 있을 것을 기대해본다.

\section{감사의 글}

본 연구는 2008년 한국연구재단의 지원을 받아 수행된 2년 차 연구임(KRF-2008-313-G00005).

\section{References}

1. Aihara, Y. 2007. Food-dependent exercise-induced anaphylaxis. Arerugi. 56, 451-456.

2. Barg, W., Medrala, W. and Wolanczyk-Medrala, A. 2011. Exercise-induced Anaphylaxis: An Update on Diagnosis and Treatment. Curr. Allergy Asthma. Rep. 11, 45-51.

3. Beaudouin, E., Renaudin, J. M., Morisset, M., Codreanu, F., Kanny, G. and Moneret-Vautrin, D. A. 2006. Food-dependent exercise-induced anaphylaxis-update and current data. Eur. Ann. Allergy Clin. Immunol. 38, 45-51.

4. Chandra, R. K., Baker, M., Whang, S. and Au, B. 1991. Effect of two feeding formulas on immune responses and mortality in mice challenged with Listeria monocytogenes. Immunol. Lett. 27, 45-48.

5. Gotua, M., Lomidze, N., Dolidze, N. and Gotua, T. 2008. IgE-mediated food hypersensitivity disorders. Georgian. Med News 157, 39-44. 
6. Greaves, M. W. 2005. Antihistamines in dermatology. Skin Pharmacol. Physiol. 18, 220-229.

7. Kim, C. H. and Kwak, Y. S. 2004. Swim training increases ovalbumin induced active systemic anaphylaxis in mice. Immund. Invest. 33, 469-480.

8. Kwak, Y. S. 2010. Studies of exercise-induced allergy anaphylaxis mechanisms and the effects of Vitamin C and catalase Supplementation in Exercise-Induced Allergy Anaphylaxis. J. Life Sci. 20, 511-518.

9. Lee, W. J., Kwak, Y. S. and Yoo, B. I. 2011. Effects of different exercise intensity on FDEIA and related mechanisms. J. Life. Sci. 4, 542-548.

10. Lemon-Mule, H., Nowak-Wegrzyn, A., Berin, C. and Knight, A. K. 2008. Pathophysiology of food-induced anaphylaxis. Curr. Allergy Asthma Rep. 8, 201-208.

11. Perez Pimiento, A. J., Fernandez, P. B., Santaolalla, M. M., De Paz Arranz, S. and Dominguez, Lazaro A. R. 2001. Exercise-induced anaphylaxis syndrome. An. Med Interna. 18, 269-273.

12. Plavec, D. and Vuljanko, I. M. 2010. Exercise-induced anaphylaxis-a review. Lijec. Vjesn. 132, 173-176.

13. Radlinska, A., Barg, W., Wolanczyk-Medrala, A. and Medrala, W. 2011. Food-dependenet exercise-induced anaphylaxis-current concepts in pathogensis, diagnostics and treatment. Pol. Merkur. Lekarski. 30, 49-51.

14. Scomparin, D. X., Grassiolli, S. Marcel, A. C. Gravena, C. Andreazzi, A. E. and Mathias, P. C. 2006. Swim training applied at early age is critical to adrenal medulla catecholamine content and to attenuate monosodium L-glutamate-obesity onset in mice. Life Sci. 79, 2151-2156.

15. Shankar, D. S. K., Ramnane, M. and Rajouria, E. A. 2010. Etiological approach to chronic urticaria. Indian J. Dermatol. 55, 33-38.

16. Silpa-archa, N., Kulthanan, K. and Pinkaew, S. 2011. Physical urticaria: prevalence, type and natural course in a tropical country. J. Eur. Acad Dermatol. Venereol. 25, 1194-1199.

17. Teo, S. L., Gerez, I. F. A., Ang, E. Y. and Shek, L. P. 2009. Food-dependent exercise-induced anaphylaxis-A review of 5 cases. Ann. Acad Med Singapore 38, 905-909.

18. Urisu, A., Ebisawa, M., Mukoyama, T., Morikawa, A. and Kondo, N. 2011. Japanese guideline for food allergy. Allergol. Int. 60, 221-236.

19. Volcheck, G. W. and Li, J. T. 1997. Exercise-induced urticaria and anaphylaxis. Mayo. Clin. Proc. 72, 140-147.

20. Woo, M. Y., Cwinn, A. A., Dickinson, G. and Yang, W. H. 2001. Food-dependent exercise-induced anaphylaxis. CJEM. 3, 315-317.

\section{초록 : 운동빈도의 차이가 식이유도 운동알레르기 질환과 관련기전에 미치는 영향 \\ 김철우 ${ }^{2}$. 곽이섭 ${ }^{1}{ }^{*}$ \\ ( ${ }^{1}$ 동의대학교 체육학과, ${ }^{2}$ 동의과학대학교 경찰행정계열)}

본 연구에서는 적절하게 알레르기가 유발되는 운동강도인 50 분간의 강도를 선정한 후 운동빈도를 서로 달리하 여 통제 그룹(S) 저빈도 그룹(F2, 주2회), 중빈도 그룹(F3, 주 3회) 및 고빈도 그룹(F5, 주5회)으로 나누어 훈련을 부여하고 OVA알부민으로 감작한 후 OVA로 challenge를 하였을 때, 알레르기 아나플락시스의 변화 양상 차이를 살펴보고 동시에 기전변화를 함께 규명하고자 하였다. 본 연구를 위해 그룹당 25마리씩 통제군(S; control sensitized, $\mathrm{n}=25)$, 저빈도 훈련군(F2, n=25), 중빈도 훈련군(F3, n=25) 및 고빈도 훈련군(F5, n=25)으로 구분하여 수영훈 련 빈도에 따른 알레르기를 유도하였을 때, 알레르기 아나플락시스를 조사하고 아울러 비장지수, 림프구의 수, 복강 ROS, ASAS, 및 싸이토카인(INF- $\gamma, \mathrm{IL}-4)$ 의 변화를 함께 측정하였다. 이 때, 알러지 아나플락시스 테스트는 그룹당 10 마리를 사용하였고, 나머지는 세포분석과 ROS 측정을 위하여 사용하였다. 본 연구결과 일반 감작군에 비하여 운동 감작군에서 알러지가 더 잘 유도됨을 알 수 있었고, 같은 운동강도 부여시 저빈도의 운동군에 비하 여 고빈도 운동군에서 알러지 반응이 더 잘 일어남을 확인 할 수 있었다. 이는 고빈도 운동군에서 현저히 증가되 는 IL-4 반응과 ASAS 반응으로 알 수 있었고, 특히 이러한 반응이 고빈도 운동그룹에서 현저히 증가하는 ROS 반응과 일치함을 확인하였다. 한편 저빈도 그룹에서는 오히려 INF- 8 의 증가와 ROS 반응이 감소하였고, ASAS 반응이 통제군보다 오히려 줄어들어 운동의 빈도가 알레르기반응과 밀접한 연관이 있음을 확인할 수 있었다. 추 후 이러한 원인에 대한 면밀한 분석이 요구되며, 알레르기 반응의 cross training 및 detraining 효과도 함께 규명 되어야 할 것으로 여겨진다. 